\title{
I.UMIBUNG
}

\section{IDENTIFIKASI GULMA PADA KEBUN SINGKONG (Manihot esculenta Crantz) DI DESA NITAKLOANG KECAMATAN NITA KABUPATEN SIKKA TAHUN 2018}

\author{
Sukarman Hadi Jaya Putra ${ }^{1}$ dan Maryani Jeclin ${ }^{1}$ \\ ${ }^{1}$ Program Studi Pendidikan Biologi, Fakultas Keguruan dan Ilmu Kependidikan, Universitas \\ Nusa Nipa, Maumere. Jln. Kesehatan, No. 3. Maumere. Sikka. NTT. \\ Korespondensi: sukarmanputra88@gmail.com
}

$\begin{array}{ll}\text { Diterima } & : \text { 26 Juni } 2019 \\ \text { Disetujui } & : 30 \text { Agustus } 2019 \\ \text { Diterbitkan } & : \text { 31 Agustus } 2019\end{array}$

\begin{abstract}
ABSTRAK
Penelitian tentang identifikasi gulma pada kebun singkong (Manihot esculenta Crantz) di Desa Nitakloang, Kecamatan Nita, Kabupaten Sikka bertujuan untuk mengetahui jenis-jenis gulma, kerapatan, indeks dominansi dan indeks keanekaragaman jenis. Penelitian ini telah dilaksanakan pada bulan Juli hingga Agustus 2018 dengan menggunakan metode transek garis. Jumlah stasiun yang digunakan adalah 4 stasiun yaitu dusun Baoponun, dusun Kojalaka, dusun Blatat, dusun Nitakloang. Masingmasing stasiun memiliki 3 transek garis. Setiap transek garis dibuat 10 plot pengambilan sampel. Hasil penelitian didapatkan 18 famili dan 31 spesies gulma. Nilai kerapatan gulma berkisar dari 0,008 ind $/ \mathrm{m}^{2}-9,116 \mathrm{ind} / \mathrm{m}^{2}$. Nilai kerapatan gulma tertinggi yaitu 9,116 ind/ $\mathrm{m}^{2}$ pada spesies Ageratum conyzoides dan nilai kerapatan gulma terendah yaitu $0,008 \mathrm{ind} / \mathrm{m}^{2}$ pada spesies Crotalaria pallida. Indeks dominansi gulma termasuk kategori dominansi rendah yaitu 0,12 dan indeks keanekaragaman jenis termasuk kategori keanekaragaman sedang yaitu $\mathrm{H}=1,1187$. Spesies gulma yang paling seringditemukan dalam setiap plot sampel adalah Ageratum conyzoides (babandotan), Euphorbia hirta (patikan), Alternanthera sessillis (rumput kremeh) dan yang paling sedikit muncul adalah Crotalaria pallida (rumput orok-orok).
\end{abstract}

Kata Kunci: identifikasi, gulma, manihot esculenta crantz, nitakloang

\begin{abstract}
Research on the identification of weeds in cassava (Manihot esculenta Crantz) in Nitakloang Village, Nita District, Sikka Regency which aims to determine the types of weeds, species density, dominance index ada weed diversity index. This research has been carried out from July to August 2018 using the line transect method. The number of stations used are the 4 states of the Baoponun center, Kojlaka, Blatat, Nitakloang. Each station has 3 line transect. Every line transects made 10 sample making plots. The results of the study were 19 families and 31 species of weeds. Weed type density values range from 0,008 ind/ $\mathrm{m}^{2}-9,116 \mathrm{ind} / \mathrm{m}^{2}$. The highest weed density is 9,116 ind/ $\mathrm{m}^{2}$ in species Ageratum conyzoides and the lowest weed type density is 0,008 ind/ $\mathrm{m}^{2}$ in species Crotalaria pallida. Weed dominance index means low dominance category that
\end{abstract}




\section{I.UMIRUNC}

is 0,12 and the diversity index is medium diversity category that is $H^{\prime}=1,1187$. Weed species that appear most frequently in each sample plot are Ageratum conyzoides, Euphorbia hirta, Alternanthera sessillis and the least appears is a Crotalaria pallidum.

Keywords: identification, weeds, manihot esculenta crantz, nitakloang

\section{PENDAHULUAN}

Tanaman pangan merupakan bahan makanan yang mengandung karbohidrat tinggi yang dikonsumsi oleh sebagian besar penduduk dunia. Singkong (Manihot esculenta Crantz) merupakan salah satu tanaman pangan yang mengandung karbohidrat. Keberadaan singkong pada awalnya banyak ditemukan tumbuh liar di hutan, kebun sendiri bahkan tumbuh di sembarang tempat. Jenis singkong yang dibudidayakan di Indonesia adalah Manihot esculenta Crantz (ubi kayu), Manihot utilissima (ketela pohon), Manihot edulis (ubi kayu) dan Manihot aipi (ubi kayu), Manihot glaziovii (singkong karet) (Sanches dan Pedro, 2002). Perkembangan berikutnya sesuai dengan permintaan pasar yang semakin meningkat, menyebabkan lahan akan budidaya singkong mengalami peningkatan, kemudian beberapa jenis singkong banyak dibudidayakan di Indonesia. Penyebaran tanaman singkong meluas ke semua propinsi di Indonesia.

Namun data beberapa tahun belakangan menunjukkan adanya penurunan produksi singkong. Data BPS tahun 2016, menjelaskan bahwa perkembangan tingkat produksi singkong di Indonesia pada tahun 2012 mencapai 24.177.372 ton; tahun 2013 mencapai 23.936.921 ton; tahun 2014 mencapai 23.436.384-ton dan tahun 2015 mencapai 21.801.401 ton (BPS Indonesia, 2016). Hal tersebut diindikasikan karena adanya penyebab kegagalan dalam panen singkong, salah satunnya adalah keberadaan gulma pada perkebunan singkong.

Produksi singkong di Nusa Tenggara Timur termasuk dalam lima besar penghasil singkong dengan luas area panen mencapai 73.929 ha. Tingkat produksi singkong di Nusa Tenggara Timur pada tiga tahun berturut-turut mengalami penurunan. Tingkat produksi singkong di Nusa Tenggara Timur pada tahun 2012 mencapai 892.145 ton; tahun 2013 mencapai 811.166 ton; tahun 2014 mencapai 677.577 dan tahun 2015 mencapai 637.315 ton (BPS NTT, 2016). 


\section{I.UMIRUNC}

Berdasarkan data BPS Kabupaten Sikka dalam wilayah Kecamatan Nita, tingkat produksi singkong di Kecamatan Nita juga terus mengalami penurunan. Pada tahun 2013 produksi singkong mencapai 4.376 ton. Pada tahun 2014 tingkat produksi singkong mencapai 2.482 ton. Penyebab turunnya produksi singkong ini, disebabkan oleh beberapa hal, salah satunya yaitu gulma.

Gulma adalah tumbuhan yang keberadaannya dapat menimbulkan gangguan dan kerusakan bagi tanaman budidaya maupun aktifitas manusia dalam mengelola usaha taninya (Barus dan Emanuel, 2003). Gulma didefinisikan sebagai tumbuhan yang tumbuh pada tempat yang tidak diinginkan oleh manusia (Hardiman dkk., 2014 ). Tumbuhan yang lebih lazim sebagai gulma biasanya cenderung mempunyai sifat-sifat atau ciri khas tertentu yang memungkinkannya untuk mudah tersebar luas dan mampu menimbulkan kerugian dan gangguan (Hardiman dkk., 2014 ).

Ilham (2014) menyatakan bahwa gulma merupakan suatu tumbuhan yang tumbuhnya tidak dikehendaki oleh manusia. Petani harus mengetahui karakteristik dari gulma, dengan tujuan untuk mempelajari cara pengendaliannya. Beberapa jenis gulma yang sering mengganggu tanaman budidaya dikelompokkan berdasarkan morfologi, siklus hidup, habitat yang tumbuh dan berdasarkan pengaruhnya terhadap tanaman.

Kehadiran gulma diantara tanaman budidaya dapat menyebabkan persaingan dalam memperebutkan unsur hara dan air lebih cepat dibanding tanaman pokok (Moenandir, 2005). Meskipun gulma tidak mengakibatkan kematian pada tanaman singkong tetapi akan menimbulkan hasil yang kurang memuaskan karena terjadi persaingan pengambilan zat hara, cahaya matahari, ruang tumbuh yang terbatas. Keberadaan gulma tersebut, secara analisis dapat dilihat dengan mengetahui kerapatan, indeks dominansi dan indeks keanekaragaman jenis. Ketiga analisis tersebut merupakan teknik dalam mengetahui kondisi suatu jenis/ spesies di suatu lokasi/ daerah. Misalnya kondisi atau keberadaan gulma yang terdapat di lokasi/ daerah pertanaman singkong tersebar secara merata/ dominan dan sebaliknya.

Kerapatan suatu spesies menunjukkan jumlah individu spesies dengan satuan luas tertentu, maka nilai kerapatan merupakan gambaranmengenai jumlah spesies tersebut pada lokasi penelitian. Dominansi untuk menunjukkan adanya jenis tertentu yang mendominansi di suatu lokasi/ daerah pertanaman singkong. Keanekaragaman jenis adalah jumlah jenis dalam suatu daerah/ lokasi yang menunjuk pada jumlah jenis 


\section{I.UMIRUNC}

dan jumlah individu setiap jenis serta sebagai suatu karakteristik tingkatan komunitas (Arrijani, 2006).

Gulma yang sering dijumpai pada tanaman budidaya singkong adalah gulma semusim atau tahunan yang mempunyai pertumbuhan sangat cepat dan dapat menghasilkan biji dalam waktu singkat sehingga cukup menyulitkan pengendaliannya karena beberapa saat setelah pengolahan tanah dan cukup air maka biji gulma akan cepat tumbuh. Beberapa jenis gulma yang sering tumbuh di lahan budidaya singkong adalah: Eleusine indica (rumput belulang), Centrosema pubescens (kacangan), Physalis angulate (ceplukan), Ageratum conyzoides (babandotan), Mimosa invisa (putri malu), Althernanthera sessillis (rumput kremeh), Amaranthus gracilis Desf (bayam daun), Euphorbia hirta (patikan), Portulaca oleracea (krokot), Borreria alata (rumput setawar), Porophyllum ruderale (rumput seungit), Croton hirtus (keroton), Crotalaria pallida (tanaman orok-orok), Heliotropium indicum L. (buntut tikus) (Nasir dkk., 2013).

Hingga saat ini umumnya cara yang dilakukan untuk mengendalikan gulma pada usaha tani adalah dengan menggunakan herbisida. Pada zaman ini telah berkembang dan beredar berbagai jenis dan merek dagang herbisida di pasaran, namun informasi secara ilmiah mengenai efektifitas dan efisiensi penggunaannya khususnya untuk jenis gulma pada tanaman singkong masih minim. Oleh karena itu, perlu pengkajian tentang jenis-jenis gulma yang ada di sekitar tanaman singkong yang kemudian digunakan untuk rujukan rekomendasi serta menjawab kebutuhan teknologi pengendalian tanaman bagi petani.

Pengkajian tentang jenis-jenis gulma pada tanaman singkong ini dapat dilakukan dengan cara identifikasi berdasarkan morfologi dari gulma itu sendiri agar mampu mengetahui bagaimana cara pengendaliannya. Oleh karena itu, peneliti tertarik untuk melakukan penelitian yang berjudul Identifikasi Gulma pada Kebun Singkong (Manihot esculenta Crantz) di Desa Nitakloang Kecamatan Nita Kabupaten Sikka Tahun 2018.

\section{METODE PENELITIAN}

\section{Tempat dan Waktu Penelitian}

Penelitian dilakukan pada kebun singkong di Desa Nitakloang Kecamatan Nita Kabupaten Sikka pada bulan Juli sampai Agustus tahun 2018. 


\section{I.UMIRUNC}

\section{1.}

\section{Alat dan Bahan}

Alat-alat yang digunakan dalam penelitian ini adalah: Meteran, Kamera, Gunting, Pisau, Kertas label, Masker, Sarung tangan, Kuadran sampel, Tali rafia, Kayu patok, Bolpoin dan buku, Kantong plastik. Adapun bahan yang digunakan dalam penelitian ini adalah: Kebun singkong.

\section{Metode Pengumpulan Data}

\section{Teknik Sampling}

Pengumpulan data dilakukan dengan menggunakan metode purposive sampling (sampel bertujuan), yaitu teknik pengambilan sampel yang akan diambil mempunyai pertimbangan tertentu. Pengambilan data yang luas arealnya belum diketahui paling efektif menggunakan cara transek (Fachrul dan Ferianita, 2008). Cara ini digunakan untuk mengidentifikasi gulma pada perkebunan singkong yaitu dengan menggunakan metode transectline (transek garis) dan plot. Penggunaan plot sampel dengan ukuran 1 $\mathrm{m} \times 1 \mathrm{~m}$ digunakan untuk mengamati gulma yang tergolong dalam tingkat semak atau herba.

\section{Teknik Pengumpulan Data}

Di dalam survei komunitas, transek garis digunakan sebagai titik acuan untuk pengambilan sampel (Fachrul dan Ferianita, 2008). Pengumpulan data di lapangan menggunakan metode eksplorasi, yaitu dengan mengadakan pengamatan terhadap jenis gulma yang ada di kebun singkong. Data yang dikumpulkan meliputi lokasi pengamatan, nama ilmiah, nama lokal dari gulma.

Pengambilan sampel dilakukan di 4 stasiun, pada setiap stasiun terdiri dari 3 transek garis sepanjang 50-meter yang dibentangkan tegak ke arah kebun singkong. Pada setiap transek garis yang dibentangkan terdapat 10 plot sampel yang masingmasing plot berukuran $1 \mathrm{~m}$ x $1 \mathrm{~m}$ yang dipasang secara acak, dengan jarak antar plot sampel $5 \mathrm{~m}$. Pada setiap stasiun terdapat tiga transek dengan jarak antara transek 10 meter. Setiap stasiun terdapat 30 plot, maka jumlah plot pengamatan seluruhnya yaitu 120 plot. Skema rancangan lokasi penelitian untuk 1 stasiun dapat dilihat pada Gambar 1. 


\section{I.UMIBUNG}

\section{r.t.}

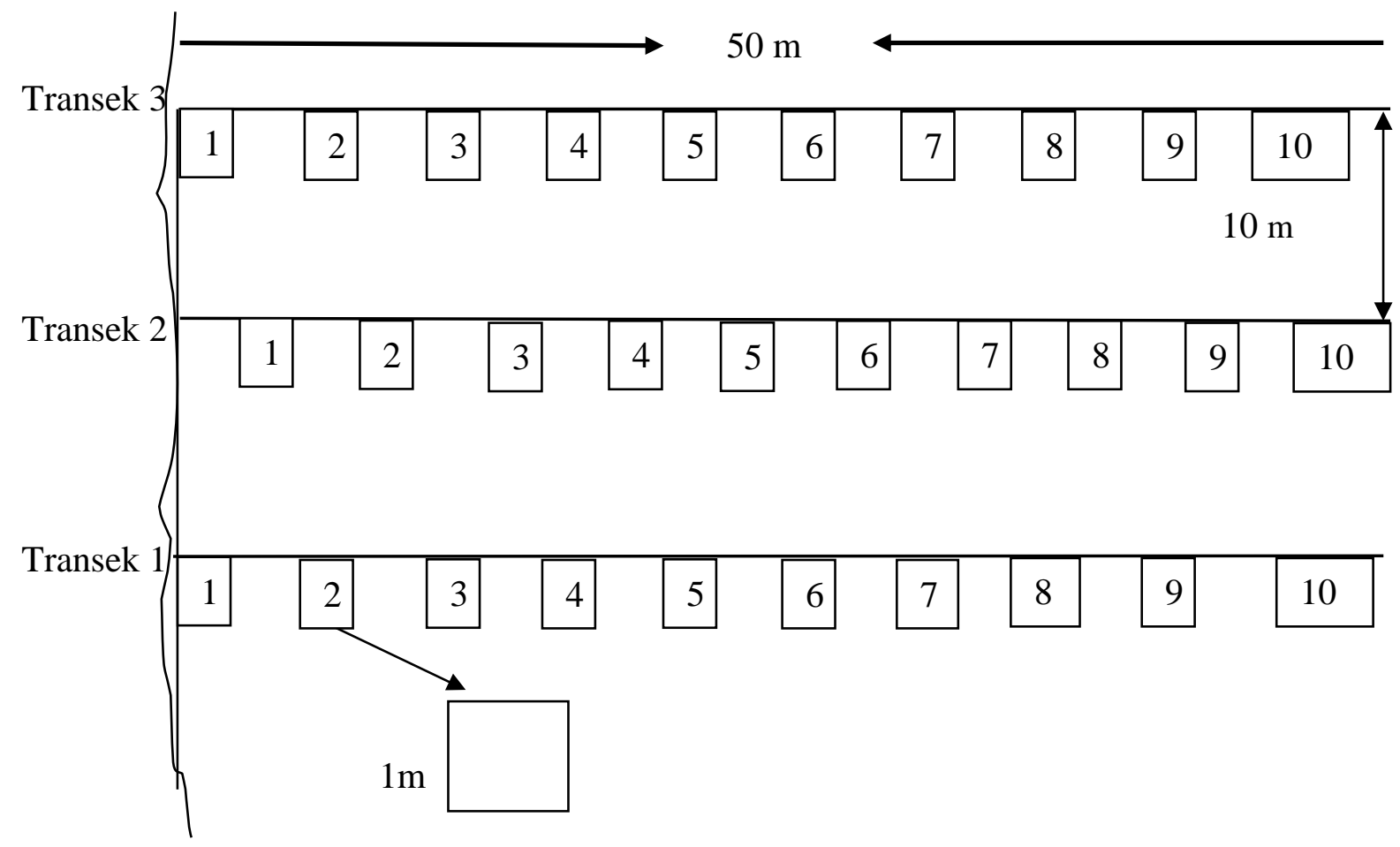

Gambar 1. Skematik Lokasi Penelitian untuk 1 Stasiun

\section{Prosedur Kerja}

1. Menentukan lokasi yang akan digunakan mengidentifikasi gulma;

2. Membuat titik awal untuk jalur pengamatan yang diberi tanda dengan kayu patok;

3. Membentangkan tali ke arah kebun singkong sepanjang 50-meter dengan jumlah transek sebanyak 3 jalur dengan jarak antar transek 10 meter;

4. Membuat plot sampel dengan ukuran $1 \mathrm{~m} \times 1 \mathrm{~m}$, kemudian dilemparkan ke atas kebun singkong secara acak;

5. Mengamati dan mencatat semua jenis gulma yang ada di dalam plot sampel tersebut;

6. Mencabut dan mengambil contoh gulma yang tidak dikenal dan dimasukkan ke dalam kantong plastik dan diberi label sesuai dengan lokasi pengamatan dan nomor plot sampelnya untuk diidentifikasi;

7. Melakukan identifikasi jenis gulma tersebut berdasarkan ciri morfologi dan pengaruhnya terhadap tanaman perkebunan;

8. Memasukkan data hasil pengamatan dengan menggunakan tabel hasil pengamatan; 


\section{I.UMIBUNG

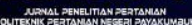

9. Mengolah data yang diperoleh dengan menggunakan rumus kerapatan, indeks keanekaragaman jenis dan indeks dominansi gulma yang terdapat pada kebun singkong di Desa Nitakloang Kecamatan Nita Kabupaten Sikka.

\section{Analisis Data}

Keanekaragaman jenis yang terdapat dalam komunitas dapat diketahui dari indeks keanekaragaman yang menurut Odum (1993) dalam Fachrul dan Ferianita (2008), rumus untuk indeks keanekaragaman dari Shannon-Wiener sebagai berikut:

$$
\mathrm{H}^{\prime}=-\sum \frac{\mathrm{ni}}{\mathrm{N}} \log \frac{\mathrm{ni}}{\mathrm{N}}
$$

Keterangan:

$\begin{array}{ll}\mathrm{H}^{\prime} & : \text { Indeks keanekaragaman Shannon-Wiener } \\ \mathrm{ni} & : \text { Jumlah individu dari suatu jenis } \mathrm{i} \\ \mathrm{N} & : \text { Total individu seluruh jenis }\end{array}$

Besarnya indeks keanekaragaman jenis menurut Shannon-Wiener didefinisikan sebagai berikut:

$$
\begin{array}{ll}
\mathrm{H}^{\prime}>3 & \text { : nilai keanekaragaman spesies tinggi. } \\
1 \leq \mathrm{H}^{\prime} \leq 3 & \text { : nilai keanekaragaman spesies sedang. } \\
\mathrm{H}^{\prime}<1 & \text { : nilai keanekaragaman spesies rendah/ sedikit. }
\end{array}
$$

\section{HASIL DAN PEMBAHASAN}

Hasil menunjukkan bahwa terdapat 31 spesies gulma di kebun singkong (Manihot esculenta Crantz). Jenis-jenis gulma yang telah diidentifikasi tersaji pada Tabel 1. Total individu gulma yang ditemukan pada kebun singkong (Manihot esculenta Crantz) di Desa Nitakloang Kecamatan Nita Kabupaten Sikka sebanyak 3605 individu dan total spesies yaitu 31 spesies. Jumlah individu terbanyak adalah spesies Ageratum conyzoides yaitu 1094 individu dan jumlah individu terendah adalah spesies Crotalaria pallida yaitu 1 individu. Ageratum conyzoides banyak ditemukan pada setiap stasiun karena dilihat dari kondisi lahan yang memungkinkan spesies ini dapat berkembang secara cepat. Spesies ini mudah tersebar dengan bantuan angin dan aliran air. 


\section{I.UMIRUNC}

Tabel 1. Hasil Identifikasi Gulma di Kebun Singkong (Manihot esculenta Crantz) di Desa Nitakloang Kecamatan Nita Kabupaten Sikka

\begin{tabular}{|c|c|c|c|c|}
\hline No & Spesies & Nama Indonesia & Nama Lokal & Jumlah \\
\hline 1 & Ageratum conyzoides & Babandotan & $\begin{array}{l}\text { Wa'an bunga } \\
\text { bura }\end{array}$ & 1094 \\
\hline 2 & $\begin{array}{l}\text { Stachytarpheta } \\
\text { jamaicensis }\end{array}$ & Pecut kuda & Kikuliluk & 310 \\
\hline 3 & Euphorbia hirta & Patikan & Nama apur & 308 \\
\hline 4 & Imperata cylindrica & Ilalang & Wa'an urun & 260 \\
\hline 5 & Nepeta cataria & Rumput ketnip & Wa'an puhun biru & 219 \\
\hline 6 & Alternanthera sessillis & Rumput kremah & Wa'an beta & 184 \\
\hline 7 & Mimosa pudica & Putri malu besar & Wa'an bei & 182 \\
\hline 8 & Ischaemum ciliare & Alang-alang & Wa'an urun & 121 \\
\hline 9 & Crhomolaena odorata & Kirinyuh & Karino & 105 \\
\hline 10 & Cyperus rotundus & Rumput teki & Derudede & 91 \\
\hline 11 & Spilanthes paniculata & Jotang & $\begin{array}{l}\text { Wa'an puhun } \\
\text { heret }\end{array}$ & 84 \\
\hline 12 & Commelina benghalensis & Rumput gewor & Wa'an mogot & 62 \\
\hline 13 & Eleusine indica & Teki ladang & Wa'an tilu gelit & 54 \\
\hline 14 & Croton hirtus & Keroton & Wa'an waun & 54 \\
\hline 15 & Centrosema pubescens & Kacangan & Sentisema & 47 \\
\hline 16 & Sonchus oleraceus & Tempuyung & Kligong & 44 \\
\hline 17 & Andrographis paniculata & Sambiloto & Sambiloto & 44 \\
\hline 18 & Themeda arguens & Rumput merak & Wa'an ti kuwut & 40 \\
\hline 19 & Phyllanthus niruri & Meniran & Wa'an pare wenit & 40 \\
\hline 20 & Cyperus digitarius & Rumput teki & Derudede & 40 \\
\hline 21 & Borreria alata & Rumput setawar & Wa'an lade & 40 \\
\hline 22 & Mimosa invisa & Putri malu & Wa'an bunga bain & 39 \\
\hline 23 & Richardia brasiliensis & Rumput goletrak & Koleng merak & 36 \\
\hline 24 & Physalis angulata & Ceplukan & Wa'an boba & 32 \\
\hline 25 & Leersia hexandra & Rumput kalamenta & Wa'an mela & 26 \\
\hline 26 & Heliotropium indicum & Tusuk konde & Wa'an teu weor & 21 \\
\hline 27 & Bidens pilosa & Rumput ajeran & Wa'an runu & 11 \\
\hline 28 & Porophylum ruderale & Rumput seugit & Wa'an ale & 8 \\
\hline 29 & Portulaca oleracia & Rumput krokot & Wa'an welang & 4 \\
\hline 30 & Passiflora foetida & Anggur hutan & Anggur uta & 4 \\
\hline 31 & Crotalaria pallida & Rumput orok-orok & Soruwowong & 1 \\
\hline
\end{tabular}

Spesies Ageratum conyzoides (babandotan) rumput ini termasuk tumbuhan berbunga, anggota dari famili Asteraceae yang banyak tumbuh di daerah tropis. Rumput 


\section{I.UMIRUNC}

ini merupakan salah satu tumbuhan pengganggu/ gulma yang potensial menghambat pertumbuhan singkong melalui akar yang mana singkong tersebut dapat kekurangan unsur hara dan tumbuhan ini dapat hidup di ladang, halaman, kebun, tepi jalan maupun tepi air (Sembodo, 2010).

Ageratum conyzoides termasuk golongan tumbuhan semusim yang menyukai intensitas cahaya tinggi dan ternaungi. Gulma ini memiliki tekstur biji ringan dengan jumlah biji yang banyak, dapat tersebar dengan bantuan angin dan cukup mengganggu perkebunan. Gulma ini banyak hidup dan sering mengintervensi ladang, kebun, teh, karet, tebu dan lain-lain (Sanches dan Pedro, 2002).

Gulma dengan jumlah individu terendah yang ditemukan adalah Crotalaria pallida yaitu 1 individu. Pada umumnya gulma ini bukan termasuk gulma pada pertanaman singkong. Gulma Crotalaria pallida merupakan tumbuhan semusim berupa herba yang tumbuh tegak. Sebetulnya gulma ini merupakan tanaman pupuk hijau. Soepadiyo dan Soejono (2011) menyatakan bahwa Crotalaria pallida merupakan jenis herba yang tumbuh dan dominan di lahan basah. Jenis ini umumnya tumbuh melimpah pada habitat lembab. Sifat inilah yang menyebabkan gulma ini sedikit tumbuh di lahan kering.

Pada lahan kering (kebun) serapan hara oleh gulma berlangsung lebih cepat, sehingga menyebabkan pertumbuhan gulma juga lebih cepatdan subur (Sastroutomo, 2003). Sukman dan Yakup (2002) menyatakan bahwa gulma sama halnya dengan tumbuhan lainnya yang membutuhkan syarat hidup dan lingkungan yang sesuai untuk pertumbuhannya. Bila lingkungan tersebut tidak lagi sesuai untuk pertumbuhannya maka gulma yang tumbuh akan berkurang jumlahnya atau tidak dapat tumbuh sama sekali pada lingkungan tersebut. Selanjutnya, Sastroutomo (2003) mengemukakan bahwa gulma yang paling banyak di lahan kering (kebun) adalah gulma dari golongan berdaun lebar.

Dari hasil penelitian yang telah dilakukan gulma yang paling mengganggu yaitu gulma Imperata cylindrica. Gulma ini yang banyak ditemukan dan yang paling mengganggu di desa Nitakloang Kecamatan Nita Kabupaten Sikka. Gulma ini merupakan gulma yang cepat tumbuh dan berkembang, mempunyai akar yang merambat kedalam tanah dan apabila petani melakukan penyiangan atau perumputan sering kali akar gulma ini tertinggal di dalam tanah sehingga akar tersebutlah yang sering cepat tumbuh. Spesies ini dapat hidup pada tempat yang lembab dan tempat yang 


\section{I.UMIRUNC}

kering, baik itu persawahan maupun di perkebunan. Spesies ini menghasilkan rimpang, penyebaran biji sangat cepat dari jarak jauh, akar dan rimpang sangat tahan terhadap api. Keadaan tanah yang digenangi air berwarna cokelat kehitaman merupakan tanah gembur yang dapat meningkatkan tingkat pertumbuhan tumbuhan pengganggu.

Tabel 1 menunjukkan bahwa perbedaan jumlah individu gulma yang didapatkan dipengaruhi oleh faktor lingkungan tempat tumbuhnya yaitu suhu, temperatur, kelembapan, tanah ruang tumbuh dan cahaya. Yang mempengaruhi jumlah spesies yang hidup pada suatu komunitas yaitu cahaya, dimana cahaya sangat berpengaruh terhadap jenis dan jumlah individu yang bisa tumbuh di tempat tersebut (Moenandir, 2005). Hal ini juga didukung oleh pernyataan Lubis (2008), bahwa masalah gulma akan berbeda pada setiap tanaman, hal ini tergantung pada lokasi, iklim dan cahaya yang diterima. Sembodo (2010) juga menyatakan, bahwa perbedaan dan perubahan lingkungan dapat mempengaruhi komposisi komunitas gulma yang menempati suatu daerah tersebut.

Jenis gulma terbanyak yaitu famili Asteraceae. Gulma famili Asteraceae dapat berkembang biak melalui biji dan mempunyai kemampuan beradaptasi dengan lingkungan dan berbunga sepanjang tahun (Flint dan Mary, 2002). Tjitrosoepomo (2002), menyatakan bahwa famili Asteraceae termasuk golongan gulma berdaun lebar dan semusim yang menyukai tanah sedikit lembab serta mampu menghasilkan biji sebanyak 40.000 pertanaman setiap tahunnya.

Ageratum conyzoides, Euphorbia hirta, Alternanthera sessillis, Spilanthes paniculata, Portulaca oleracia, Borreria alata, Richardia brasiliensis merupakan contoh spesies gulma berdaun lebar, jenis gulma ini banyak tumbuh pada saat tanaman singkong masih berumur sekitar satu bulan sampai tanaman singkong mulai berumbi. Gulma ini dapat menghambat pertumbuhan singkong dan sering juga menjadi tempat berkumpulnya hama pada tanaman singkong. Keberadaan gulma pada areal pertanaman budidaya dapat menimbulkan kerugian baik dari segi kuantitas maupun kualitas produksi.

Kerugian yang ditimbulkan oleh gulma berdaun lebar diantaranya penurunan hasil produksi akibat persaingan atau kompetisi dalam perolehan sumber daya (air, udara, unsur hara dan ruang hidup), menjadi inang hama dan penyakit, dapat menyebabkan tanaman keracunan akibat senyawa racun yang dimiliki gulma (alelopati), menyulitkan pekerjaan lapangan dan dalam pengolahan hasil serta merusak atau menghambat penggunaan alat pertanian. Kerugian-kerugian tersebut merupakan alasan kuat mengapa gulma harus diidentifikasi sehingga gulma harus dikendalikan. 


\section{I.UMIRUNC}

Selanjutnya bila ditinjau dari nilai kerapatan, indeks dominansi dan indeks keanekaragaman menunjukkan perbedaan dari masing-masing nilai yang terendah dan tertinggi. Uraian yang lebih lengkap dapat dilihat pada Tabel 2 berikut.

Tabel 2. Hasil Analisis Indeks Keanekaragaman jenis (H')

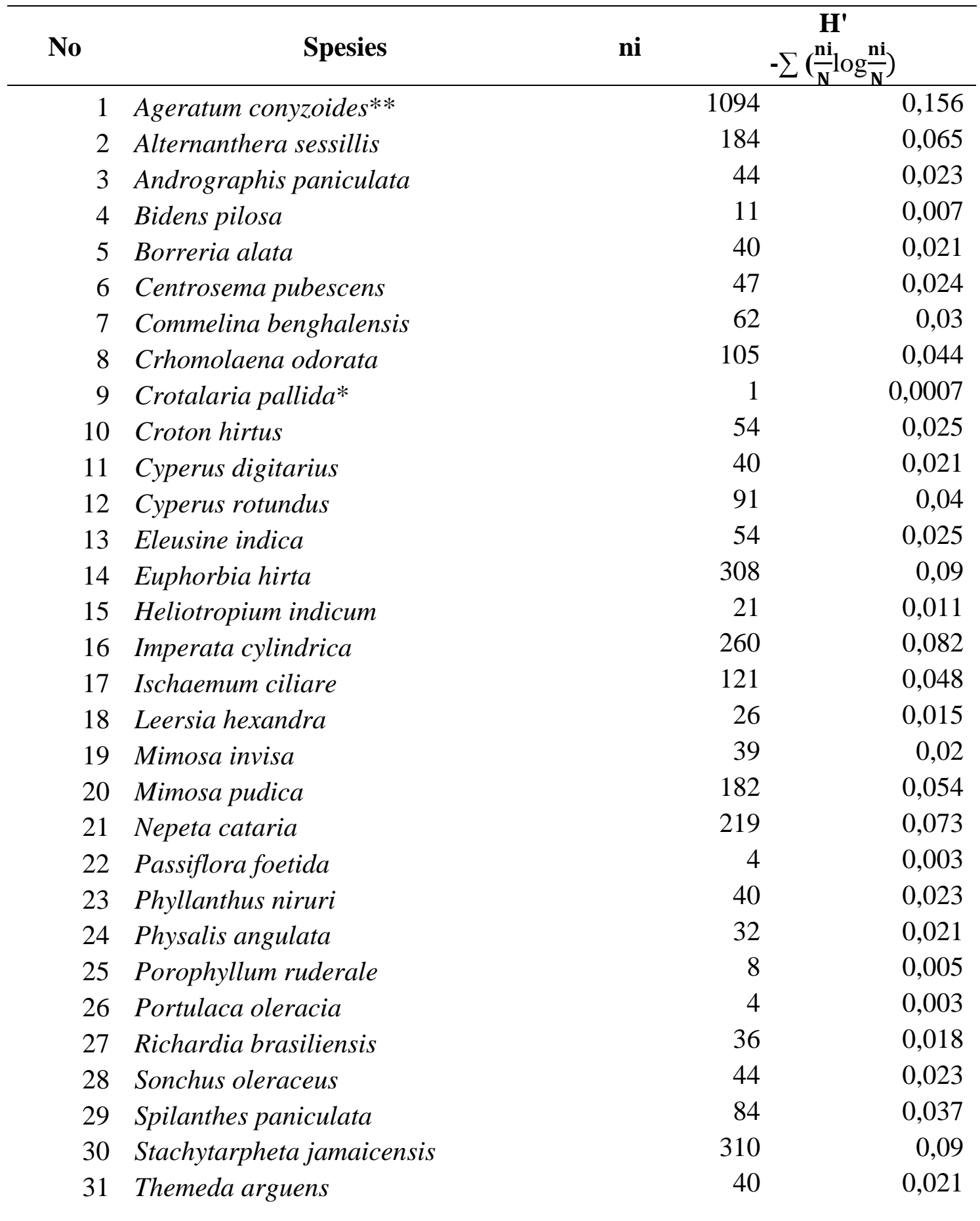

Total

Keterangan : ni : Jumlah individu jenis ke-i

$\mathrm{N}$ : Total seluruh individu 


\section{I.UMIRUNC}

$\begin{array}{ll}\text { A } & \text { : Luas pengambilan sampel }\left(\mathrm{m}^{2}\right) \\ * * & : \text { Kerapatan tertinggi } \\ * & : \text { Kerapatan terendah } \\ \mathrm{H}^{\prime} & \text { : Indeks keanekaragaman jenis }\end{array}$

Indeks Shannon-Wiener $\left(\mathrm{H}^{\prime}\right)$ tidak menilai keanekaragaman dari segi masingmasing spesies tumbuhan, melainkan menilai dari tingkat keanekaragaman tumbuhan dari segi kondisi lahan. Suatu komunitas dikatakan memiliki keanekaragaman jenis yang tinggi jika komunitas itu disusun oleh banyak jenis. Sebaliknya suatu komunitas dikatakan memiliki keanekaragaman jenis yang rendah apabila komunitas tersebut disusun oleh jenis yang sedikit. Data dan hitungan hasil penelitian, diperoleh nilai indeks keanekaragaman jenis $\left(\mathrm{H}^{\prime}\right)$ gulma di kebun singkong (Manihot esculenta Crantz) pada setiap stasiun di Desa Nitakloang Kecamatan Nita Kabupaten Sikka tercantum pada Tabel 2.

Tabel 2 menunjukkan bahwa indeks keanekaragaman jenis $\left(\mathrm{H}^{\prime}\right)$ gulma di kebun singkong (Manihot esculenta Crantz) di Desa Nitakloang Kecamatan Nita Kabupaten Sikka, diperoleh nilai $H^{\prime}=1,1187$. Dari nilai tersebut menunjukkan bahwa ekosistem lahan penelitian keanekaragaman yang termasuk dalam kategori sedang dan dapat menurunkan tingkat produksi singkong di lokasi/ daerah pertanaman singkong di Desa Nitakloang Kecamatan Nita Kabupaten Sikka. $1 \leq \mathrm{H}^{\prime} \leq 3$ menunjukkan keanekaragaman sedang, produktivitas cukup, kondisi ekosistem cukup seimbang, tekanan ekologis sedang (Fitriani, 2006).

Secara keseluruhan terjadi penurunan keanekaragaman tumbuhan pada suatu waktu dikarenakan masing-masing tumbuhan membutuhkan waktu yang berbeda-beda dalam menyelesaikan masa hidupnya. Keanekaragaman awal ditunjukkan oleh tumbuhan annual. Tumbuhan annual hanya membutuhkan waktu 1 tahun/ musim dalam menyelesaikan siklus hidupnya. Tumbuhan ini mampu tumbuh sangat cepat dan mengahasilkan biji dalam periode yang amat singkat.

Selanjutnya terjadi pergeseran keanekaragaman tumbuhan penyusun lahan oleh tumbuhan binneal. Tumbuhan tersebut membutuhkan waktu 2 musim dalam menyelesaikan siklus hidupnya. Pada akhirnya keanekaragaman ditunjukkan oleh tumbuhan perennial. Tumbuhan tersebut merupakan tumbuhan yang mampu tumbuh terus menerus selama lebih dari 2 musim dari sistem perakaran yang sama (Mardiyanti dan Erlinda, 2010). 


\section{I.UMIRUNC}

\section{KESIMPULAN}

Berdasarkan hasil penelitian mengenai identifikasi gulma pada kebun singkong (Manihot esculenta Crantz) di Desa Nitakloang Kecamatan Nita Kabupaten Sikka pada tahun 2018 yang telah dilaksanakan, dapat disimpulkan bahwa gulma yang ditemukan sebanyak 31 spesies dari 18 famili yaitu famili Achanthaceae, Amaranthaceae, Asteraceae, Boraginaceae, Commelinaceae, Cyperaceae, Euphorbiaceae, Fabaceae, Graminaceae, Lamiaceae, Leersiaceae, Papilionaceae, Passifloraceae, Poaceae, Portulacaceae, Rubiaceae, Solanaceae dan Verbenacea.

\section{DAFTAR PUSTAKA}

Arrijani. 2006. Analisis Vegetasi. HuluDAS Cianjur Taman Nasional Gunung Gede Pangrango

Fachrul dan Ferianita M. 2008. Metode Sampling Bioekologi. Jakarta: Bumi Aksara

Fitriani, Y. R. 2006. Keanekaragaman dan Kemelimpahan Makrozoobenthos di Hutan Mangrove Hasil Rehabilitasi Taman Hutan Raya Ngurah Rai Bali. Biodiversitas $7(1): 67-72$

Hardiman, Tomy., Islami, Titiek., Sebayang T., dan Husni. 2014a . Pengaruh Waktu Penyiangan Gulma pada Sistem Tanam Tumpangsari Kacang Tanah(Arachis hypogaea 1.) dengan Ubi Kayu (Manihot esculenta crantz.). Jawa Timur: Jurnal Produksi Tanaman. Vol. 2, No. 2

Hardiman, Tomy., Islami, Titiek., Sebayang T., dan Husni. 2014 ${ }^{\mathrm{b}}$. Effect Time of Weeding in Intercropping System Peanuts (Arachis hypogaea L) with Cassava (Manihot esculenta Crantz.). Jurnal Produksi Tanaman. Universitas Brawijaya Malang

Ilham, Jumaidi. 2014. Identifikasi dan Distribusi Gulma di Lahan Pasir Pantai Samas, Kabupaten Bandul, Daerah Istimewah Yogyakarta. Jakarta Selatan: Planta Tropika Journal of Agro Science. Vol. 2, No.2

Flint F dan Mary. 2002. Pengendalian Hama Terpadu. Kanisius: Yogyakarta

Lubis A.U. 2008. Tanaman Singkong (Manihot esculenta) di Indonesia. Edisi 2. Pusat Penelitian. Medan. Sumatera Utara

Mardiyanti dan Erlinda D. 2010. Dinamika Keanekaragaman Spesies Tumbuhan Pasca Pertanaman Padi. Malang: Jurnal Produksi Tanaman Vol. 1, No. 1

Moenandir.J. 2005. Ilmu Gulma Dalam Sistem Pertanian. Jakarta: Rajawali Grafindo 


\section{I.UMIBUNG}

Odum, E. P. 1993. Dasar-dasar Ekologi: Terjemahan dari Fundamentals of Ecology. Alih Bahasa Samingan, T. Edisi Ketiga. Universitas Gajah Mada Press, Yogyakarta

Nasir S., Mudji R., Sri W.I., Budhi S. R., dan Sri W. 2013. Hama, Penyakit dan Gulma pada Tanaman Ubi Kayu. Jakarta: IAARD Press

Sanches A. dan Pedro. 2002. Sifat dan Pengelolaan Tanah Tropika. Bandung: ITB

Sastroutomo, S.S. 2003. Ekologi Gulma. Jakarta: PT Gramedia Pustaka Utama

Sembodo, D. R. J. 2010. Gulma dan Pengolahannya. Edisi Pertama. Penerbit Graha Ilmu: Yogyakarta

Soepadiyo dan Soejono. 2011. Ilmu Gulma dan Pengelolaan pada Budi data Perkebunan. Yogyakarta: Gajah Mada University Press

Sukman. Y. dan Yakup. 2002. Gulma dan Teknik Pengendaliannya. Jakarta: Rajawali

Tjtrosoepomo, G. 2002. Taksonomi Tumbuhan (Spermatophyta). UGM Press. Yogyakarta 